
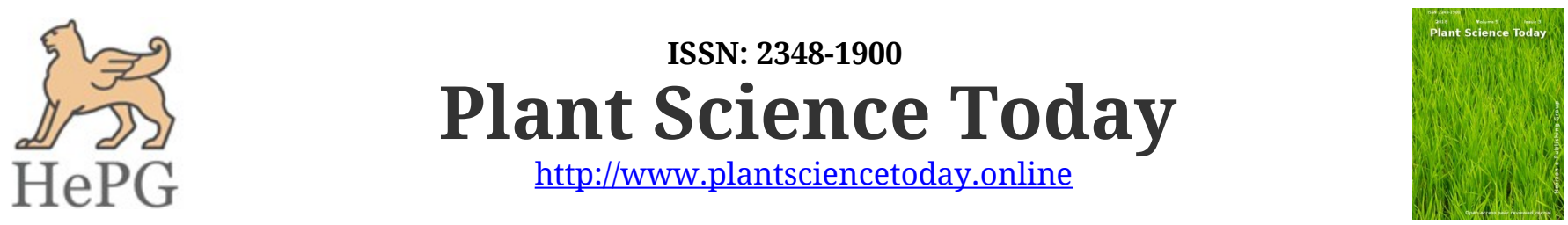

Research Article

\title{
Ophiorrhiza mungos var. angustifolia - Estimation of camptothecin and pharmacological screening
}

\author{
Krishna Kumar $\mathbf{G}^{1^{*}}$, Muhammed Fayad $\mathrm{A}^{2}$, Jayakumaran Nair $\mathrm{A}^{\mathbf{1}}$ \\ ${ }^{1}$ Department of Biotechnology, Kariavattom Campus, University of Kerala, Thiruvananthapuram 695581, India \\ ${ }^{2}$ Sree Narayana Institute of Technology, Kollam, Kerala, Vadakkevila, Kollam 691010. India
}

\section{Article history}

Received: 01 May 2018

Accepted: 07 July 2018

Published: 17 July 2018

\section{Copyright}

(C) Kumar et al (2018). This is an open-access article distributed under the terms of the Creative Commons Attribution License, which permits unrestricted use, distribution, and reproduction in any medium, provided the original author and source are credited.

\section{Editor}

Fatima LAMCHOURI, Sidi

Mohamed Ben Abdellah

University of Fez B.P., Morocco

\section{Publisher}

Horizon e-Publishing Group

\section{*Correspondence}

Krishna Kumar G

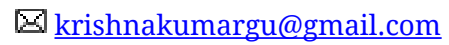

\begin{abstract}
Ophiorrhiza mungose var. angustifolia (Thwaites) Hook. f (Family- Rubiaceae) is a recently identified plant from Ophiorrhiza species in Western Ghats of Kerala. The plant is a promising candidate for the production of camptothecin (CPT) - a high value anticancer compound. Preliminary screening of hexane and methanol extract revealed the presence of phenolics, flavonoids, caumarins, steroids, terpeanoids, saponins, carbohydrates and alkaloids. Camptothecin was estimated from methanol extract using high performance liquid chromatography and the level of CPT was $297.94 \pm 2.27$ $\mu \mathrm{g} / \mathrm{g}$ dry weight. The in vitro antioxidant assay revealed both extract showed moderate level of total phenolic content, 2,2-diphenyl-1-picrylhydrazyl (DPPH) radical scavenging assay, ferric chloride reducing power assay, phospho-molybdate assay of total anti-oxidant capacity and nitric oxide scavenging activity assay. Antimicrobial study reveals that only hexane extract inhibits pathogenic bacteria and fungus. Overall these findings will lead to isolation of active compounds other than camptothecin, elucidate them against wider range of bioactivity studies to find new therapeutic principles.
\end{abstract}

\section{Keywords}

Phytochemistry; antioxidant; antimicrobial; Ophiorrhiza; Pharmacological screening

\section{Citation}

Kumar G K, Fayad A M, Nair A J. Ophiorrhiza mungos var. angustifolia - Estimation of camptothecin and pharmacological screening. Plant Science Today 2018;5(3):113-120. https://dx.doi.org/10.14719/pst.2018.5.3.395

\section{Introduction}

Ophiorrhiza belongs to the dicotyledonous family Rubiaceae and is represented by 150 species, distributed mainly in the Indo-Malay region (1). Southern western Ghats of India is considered as a rich repository of Ophiorrhiza as evidenced by the survey reports showed, 21 species and 2 varieties, of which 13 species are endemic $(2,3,4,5)$. Other important phytochemicals, including derivative of CPT, pumiloside, luteolin, harman, tetrahydro alastonine, bracteatine, blumeanine, strictosidinic acid, lyalosidic acid are also present in varying quantities in certain species of Ophiorrhiza (6).

Camptothecin (CPT), a monoterpnene indole alkaloid and is regarded as one of the potent inhibitor of topoisomerise 1. CPT and its derivatives are also reported to be very active anticancer agents against colorectal and ovarian cancer $(7,8)$. CPT originally isolated from Camptotheca acuminata (9) is also reported in Nothapodytes foetida (10), Tabernaemontana heyneana (11) and various Ophiorrhiza spp. (12). 
O. mungos var. angustifolia is distributed all over peninsular India and Sri lanka (13), and is commonly called Indian snake root or mangoose plant. The plant is reported to have second highest CPT content among different Ophiorrhiza species in the southern Western Ghats (12). Recent reports reveals, owing to higher level of camptothecin in $O$. mungos var. angustifolia researchers develop an efficient in vitro regeneration protocol for the propagation and production of CPT from this species (14). Phytochemicals other than camptothecin such as phenolics, favanoids, coumarins, steroids, terpaoids and alkaloids are reported from in $O$. mungos and $O$. prostrata where they act as antioxidants and free radical scavengers (15). So far no extensive in vitro antioxidant and antimicrobial screening have been reported on $O$. mungos var. angustifolia. The main objective of the present study to carry out the qualitative and quantitative evaluation of camptothecin, estimation of total phenolic compounds and evaluation of in vitro antioxidant activity and antimicrobial activity of $O$. mungos var. angustifolia.

\section{Materials and methods}

The whole plant of $O$. mungos var. angustifolia (Fig. 1A) was collected in June 2017 from Idukki Munnar - Neriyamangalam (Latitude $10.061774^{\circ} \mathrm{N}$; Longitude $76.760652^{\circ}$ E). The whole plant was identified and authenticated the authors. A voucher specimen (No. TBGT79923) has been deposited at Jawaharlal Nehru Tropical Botanic Garden and Research Institute, India.

\section{Preparation of plant extract}

The dried and ground plant material (20 g) was successively extracted with hexane and methanol $5 \mathrm{~h}$ each. The extracts were concentrated to dryness under reduced pressure using rotaevaporator (Heidolf, Germany). The completely dried extract was used for further analysis.

\section{Preliminary phytochemical screening}

Initial phytochemical screening was done with previously described methods: Phenolics (Ferric chloride test), flavonoids (Shinoda test), steroid (Liebermann-Burchard's test), terpenoids (Salkowaski test), saponins (Frothing test), coumarins, carbohydrates (Molishes test) and alkaloids (Wagenrs test, Mayer test and Dragondroff's test) (16).

\section{Qualitative assay of camptothecin - Thin layer chromatography (TLC)}

The active phytochemical camptothecin in $O$. mungos var. angustifolia was detected and estimated using TLC. $20 \mu \mathrm{L}$ of standard camptothecin $(\mathrm{mg} / \mathrm{mL}$ in methanol) and methanol extracts of plant were loaded on a precoated TLC plate $(5 \times 10 \mathrm{~cm}$, Silica gel 60 F254) (Merck,
Germany) and chromatographed in the solvent systems toluene: acetonitrile: glacial acetic acid $(65: 35: 1 \mathrm{v} / \mathrm{v} / \mathrm{v})$ (14). The co-chromatographed authentic sample of CPT was used to detect the presence of CPT in the sample lane on the TLC plate under the UV chamber and $R_{f}$ value was calculated (17).

\section{Quantitavie assay - HPLC Estimation}

The methanol extract of $O$. mungos var. angustifolia was analysed using HPLC Shimadzu Japan). The system attached a UV/VIS Detector (Prominance SPD M20 A diode array detector). Data acquisition and instrumental control were performed using Shimadzu Lab solution version 5.73. Separation of the compounds was performed on a general purpose Shimadzu C-18 column ( $250 \times 4.6 \mathrm{~mm}, 5 \mu \mathrm{m}$ particle size, $5 \mu \mathrm{m})$ and the isocratic mobile phase consisted of $100 \%$ methanol (Spectrochem, India - HPLC grade). The flow rate was $1.0 \mathrm{ml} / \mathrm{min}$ and the injection volume was $10 \mu \mathrm{L}$. Pump consists of (LC 6 AD) system interface (CBM-20A) and a high pressure adjustable volume dynamic mixer. The analysis was performed at room temperature $\left(25^{\circ} \mathrm{C}\right)$ and the compound was detected at $254 \mathrm{~nm} .1$ - 500 ppm of authentic sample was run in HPLC column for calibration curve. Plant extract filtered using a $0.22 \mu \mathrm{m}$ filter (Millipore) inject separately. At the same retention time of standard the peak area of the extracts were measured and quantified using the equation from the calibration curve, $\mathrm{f}(\mathrm{x})=21648.5^{*} \mathrm{x}+8030.52$. The results are expressed in mean \pm standard deviation (18).

\section{In vitro Pharmacological screening of $O$. mungos var. angustifolia}

Estimation of phenolics using Folin Ciocalteu method: Total phenolic contents of each extract were determined using a modified Folin-Ciocalteu colorimetric method (19). Folin ciocalteu method is a simple procedure to estimate the total phenolics and thus total reducing power of the extracts. Different concentrations $(10-100 \mathrm{mg} / \mathrm{mL})$ of the extract were transferred to reaction tubes and were made up to $0.5 \mathrm{~mL}$. To this $3 \mathrm{~mL}$ of water was added followed by Folin Ciocalteu Phenol reagent. Immediately $0.75 \mathrm{~mL}$ of $20 \%(\mathrm{w} / \mathrm{v})$ sodium carbonated was added, followed by $0.95 \mathrm{~mL}$ of water. The reactants were mixed and were incubated for $30 \mathrm{~min}$ at $30^{\circ} \mathrm{C}$. The absorbance was measured at $765 \mathrm{~nm}$ using a UV-visible spectrometer. A standard curve method was adopted for the estimation, using 5 different concentrations of the extracts. Gallic acid (1 $\mathrm{mg} / \mathrm{mL}$ ) served as the positive control; the reducing power was expressed as gallic acid equivalent (GAE).

2,2-diphenyl-1-picrylhydrazyl (DPPH) radical scavenging assay: The antioxidant activity of the extract was determined by the 1,1-diphenyl-2picryl-hydrazyl (DPPH) assay, as described earlier 

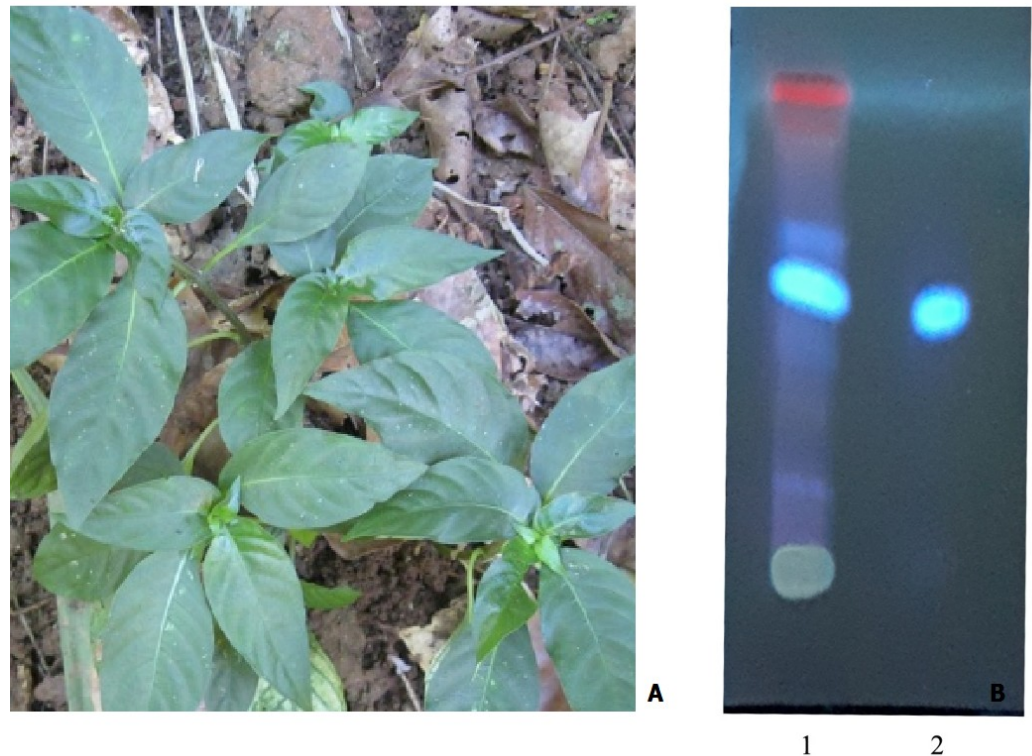

Fig. 1. A. Ophiorhiza mungos var. angustifolia (Thwaites) Hook.f (in wild); B. TLC profile of methanol extract of $O$. mungos var. angustifolia

with some modifications (20). Briefly 100 - $500 \mu \mathrm{g} /$ $\mathrm{mL}$ of the plant extract were taken in $5 \mathrm{~mL}$ screw cap tubes and were made up to $1 \mathrm{~mL}$ with methanol. $1 \mathrm{~mL}$ of methanol devoid of extracts served as the control. To these tubes $1 \mathrm{~mL}$ of $0.2 \mathrm{M}$ of DPPH solution in methanol was added and incubated for $1 \mathrm{~h}$ at room temperature. Ascorbic acid served as a comparative control. The absorbance was measured at $517 \mathrm{~nm}$ in a UVVisible spectrometer (UV2100, Shimadzu Corporation, Japan). Ascorbic acid is used as the positive control. The anti-oxidant activity was measured as $50 \%$ radical scavenging activity $\left(\mathrm{IC}_{50}\right.$ value) by the formula:

$$
\% \text { Inhibition }=\frac{\text { OD control }- \text { OD of test }}{\text { OD of control }} \times 100
$$

Ferric chloride reducing power assay: Various concentrations of the samples were taken and were made up to $0.5 \mathrm{~mL}$ with $0.2 \mathrm{M}$ phosphate buffer (pH 6.6). To this $1 \mathrm{~mL}$ of $1 \%(\mathrm{w} / \mathrm{v})$ potassium ferric cyanide is added and shaken well incubated at $50^{\circ} \mathrm{C}$ for $20 \mathrm{~min}$ in a water bath. At the end of the $20 \mathrm{~min}$ of $10 \%$ TCA was added and mixed. Then $1.5 \mathrm{~mL}$ of water was added to this mix followed by addition $0.3 \mathrm{~mL}$ of ferric chloride. The colour developed was measured spectrometrically. Ascorbic acid was used a comparative control (21).

Phospho-molybdate assay of total anti-oxidant capacity: The extracts were taken at desired concentrations and were made up to $200 \mu \mathrm{L}$ with water. To these tubes $2 \mathrm{~mL}$ of phosphomolybdate reagent is added and was incubated at $90^{\circ} \mathrm{C}$ for 90 $\mathrm{min}$. The increase in the green colour in relation to the antioxidant content of the extract is evaluated by the increase in absorbance of the test sample. The absorbance was measured at $695 \mathrm{~nm}$ in UVVisible spectrophotometer (Shimadzu, Japan). A standard curve method was adopted for the estimation, using 5 different concentration of the extracts. Gallic acid was used as positive control (22).

Nitric oxide scavenging activity assay: The nitric oxide scavengers in the extracts mop measured spectrometrically. Various concentrations of the extracts were taken in the reaction tube and were made up to $0.5 \mathrm{~mL}$ with $0.01 \mathrm{M}$ PBS (pH 7.4). To this $10 \mathrm{mM}$ of sodium nitroprusside (SNP) dissolved in 0.01 M PBS (pH 7.4) was added and mixed. The tubes were then incubated for $2 \mathrm{~h}$ at $30^{\circ} \mathrm{C}$. Post incubation, $0.5 \mathrm{~mL}$ of Greiss's reagent was added to the samples and mixed and incubated for $20 \mathrm{~min}$. The colour developed was spectrometrically measured at $546 \mathrm{~nm}$ in a UVVisible spectrophotometer (Shimadzu, Japan). A standard curve method was adopted for the estimation, using 5 different concentrations of each of the extracts (23).

Antimicrobial assay: The agar well diffusion method was performed to screen for antimicrobial activity of hexane and methanol extracts of $O$. mungos var. angustifolia (24). The gram positive bacteria (Escherichia coli, Salmonella typhi and Klebsiella pneumoniae), gram negative bacteria (Stephylococcus aureus and Bacillus subtilis) and fungal strains (Aspergillus niger and Colletotrichum) were used for the present study. The both extracts were taken as $\mathrm{mg} / \mathrm{mL}$ in DMSO and streptomycin was prepared in sterile distilled water as positive control and negative control was pure DMSO. Nutrient medium (Merck) for bacteria and Saboured Dextrose media (SDA) (Himedia, Bangalore) for fungus was prepared according the manufactures instruction.

Nutrient and SD broth were prepared in test tubes and plugged with non-adsorbent cotton; bacterial and fungal cultures were inoculated in the appropriate medium from the stock and kept in rotor evaporator for overnight at $100 \mathrm{rpm}$. Nutrient agar and SD agar medium were 
mAU
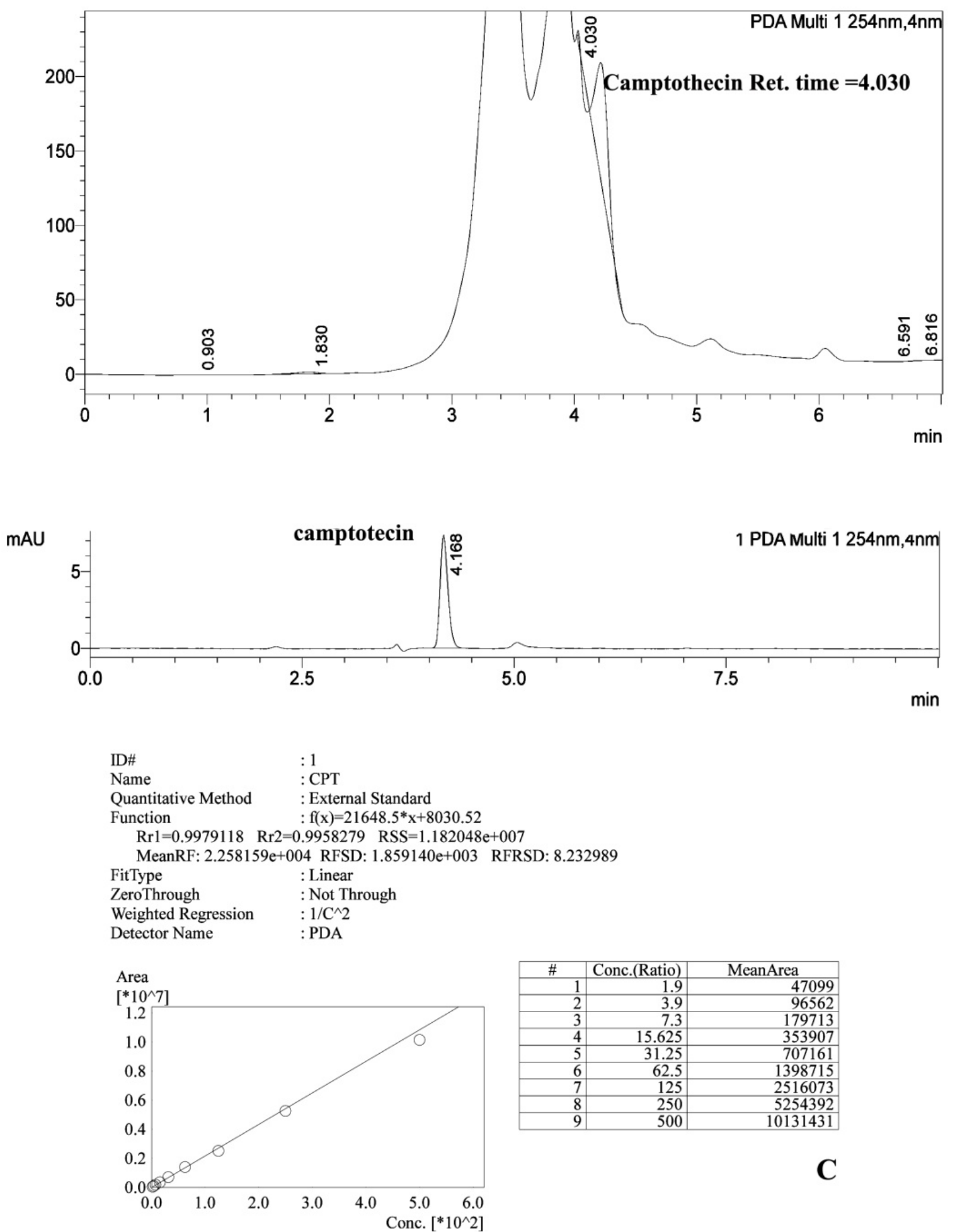

Fig. 2. HPLC chromatography of camptothecin in $O$. mungos var. angustifolia. A. Camptothecin in crude extract; B. Standard camptothecin; C. Calibration curve.

immediately after autoclaving, it was cooled and $20 \mathrm{~mL}$ each dispensed into glass petri dishes to give a uniform depth of approximately $4 \pm 0.5 \mathrm{~mm}$. The $100 \mu \mathrm{L}$ of turbid bacterial and fungal suspension were inoculated and swabbed. Wells of $6 \mathrm{~mm}$ size were made using sterile cork borer and the rim of the agar is swabbed. Plant extracts and controls were then dispensed $(50 \mu \mathrm{L})$ into the wells, the plates are then sealed with para film and incubated at $37^{\circ} \mathrm{C}$ for $18-24 \mathrm{~h}$. After $18-24 \mathrm{~h}$ of incubation, each plate is examined. The diameter of the zones of compete inhibition were recorded in the test as well as the control well. Assay was done three times and average of inhibition zone with standard deviation was calculated.

\section{Statistical Analysis}

Statistical analysis was carried out with IBM SPSS statistics ver. 20, and results are expressed as means \pm standard deviation. 
Table 1. Antioxidant effect ( $\mathrm{IC}_{50}$ value, $\mu \mathrm{g} / \mathrm{mL}$ ) on DPPH radicals, Ferric chloride reducing power assay, Nitric oxide and Phospho-molybdate assay for hexane and methanol extract of $O$. mungos var. angustifolia.

\begin{tabular}{lrrr}
\hline Radical scavenging assay & Hexane extract & Methanol extract & *Standard \\
\hline DPPH & $65.3 \pm 4.9$ & $66.6 \pm 5.6$ & $03.3 \pm 0.1$ \\
Ferric chloride reducing power assay & $256.0 \pm 5.2$ & $110.0 \pm 10.7$ & $33.3 \pm 1.3$ \\
Nitric oxide & $105.2 \pm 5.0$ & $328.7 \pm 7.6$ & $85.98 \pm 5.0$ \\
Phosphomolybdate assay for total antioxidant assay & $600.8 \pm 2.0$ & $925.4 \pm 15.0$ & $24.8 \pm 1.0$ \\
\hline
\end{tabular}

*Standard for DPPH, Ferric chloride - ascorbic acid; Phsphomolibdate, Nitric oxide - Gallic acid. Each value in the Table is represented as mean \pm SD $(n=3)$. Means not sharing the same letter are significantly different (LSD) at $p<0.01$ probability level in each column.

\section{Results and discussion}

\section{Extraction yield}

The yield of extraction depends on the solvent with varying polarity, temperature, extraction time, and composition of the sample. In this work, O. mungos var. angustifolia, hexane and methanol extracts gave $6.75 \%$ and $15.58 \%$ respectively by soxhlet method. In the present study extreme low and high polar solvents were selected where as the camptothecin is a polar compound and can be extracted with methanol or chloroform $(12,17)$ while the previous report states that methanol is more suitable solvent for camptothecin isolation $(12,15)$. This shows that the extraction yield increases with increasing polarity of the solvent used in extraction. The antioxidant and antimicrobial activity also tested the same solvent extracts. The results of this study are in agreement with the extraction yields of rice bran (25) and some medicinal plants (26).

\section{Preliminary phytochemical screening}

The phytochemical investigation of the hexane and methanol extracts of $O$. mungos var. angustifolia revealed that phenolics, coumarins, flavonoids, steroids, terpenoids, saponins carbohydrate and alkaloid were present in the extract. In the present study qualitative evaluation of the chemical constituents of methanol extract of $O$. mungos var. angustifolia showed the presence of various classes of compounds including, phenolics, saponins, terpenes, steroids, carbohydrates and alkaloids. The presence of these classes of compounds contributes different biological activities. This might be attributed to their free radical scavenging, anti-microbial and anticancer activities $(27,28)$.

\section{Qaulitative Assay of camptothecin - Thin layer chromatography (TLC)}

Different solvent systems were tried to standardize the TLC fingerprint profile of $O$. mungos var. angustifolia along with camptothecin as a marker compound Fig. 1B. Toluene: acetonitrile: glacial acetic acid (65:35:1 v/v/v) gave well resolved camptothecin band for the methanolic extract and showed a dark blue spot at $366 \mathrm{~nm}$, with the same $R f$ value (0.43) The thin layer chromatography
(TLC) fingerprint profile emphasizes that (1) applicability in authentication and (2) forming an important component of quality control criteria (29). There are several reports available with several solvent system used separation of camptothecin from several plant species viz. Nothapodytes foetida- chloroform: ethanol (24:1 v/ v) (13), Ophiorrhiza mungos- ethyl acetate: ethanol (3:1 v/v) (30) Camptotheca acuminata- chloroform: ethanol: ethyl acetate: hexane (20:9.5:6.5:5.3 v/v/v/ v) (31) and chloroform: ethanol (15:1 v/v) (22).

\section{Quantitative assay of camptothecin - HPLC Estimation}

Estimation of camptothecin is measured using Standard graph method in HPLC is $297.94 \pm 2.27$ $\mu \mathrm{g} / \mathrm{g}$ dr. wt. (Fig. 2). The retention time of camptothecin is $4.184 \mathrm{~min}$. Several approaches have been employed for the analysis of CPT, mainly high performance liquid chromatography (HPLC) (32). Recently, alternative simple and sensitive methods involving HPLC coupled with mass selective detection have been improved and these have been shown to be more accurate than conventional HPLC system.

\section{Pharmacological screening}

\section{Total phenolic content}

The total phenolic content of the hexane extract, calculated from the calibration curve $(R 2=0.998)$, was $27.28 \pm 0.579$ gallic acid equivalents/g, and methanol extract $(R 2=0.999)$ was $60.67 \pm 0.760$ gallic acid equivalents/g (Fig. 3; Table 1). Phenolic compounds have redox properties, which allow them to act as antioxidants (33). The free radical scavenging ability of plant extract helped by their hydroxyl groups, the total phenolic concentration could be used as a basis for rapid screening of antioxidant activity. As this is the first report on the antioxidant activity of $O$. mungos var. angustifolia through phytochemical analyses should be done to identify the active phenolic components from both extracts.

\section{In vitro anti oxidant assay}

Antioxidant potential of $O$. mungos var. angustifolia was determined by using DPPH, Ferric chloride reducing power assay, Phosphomolybdate 


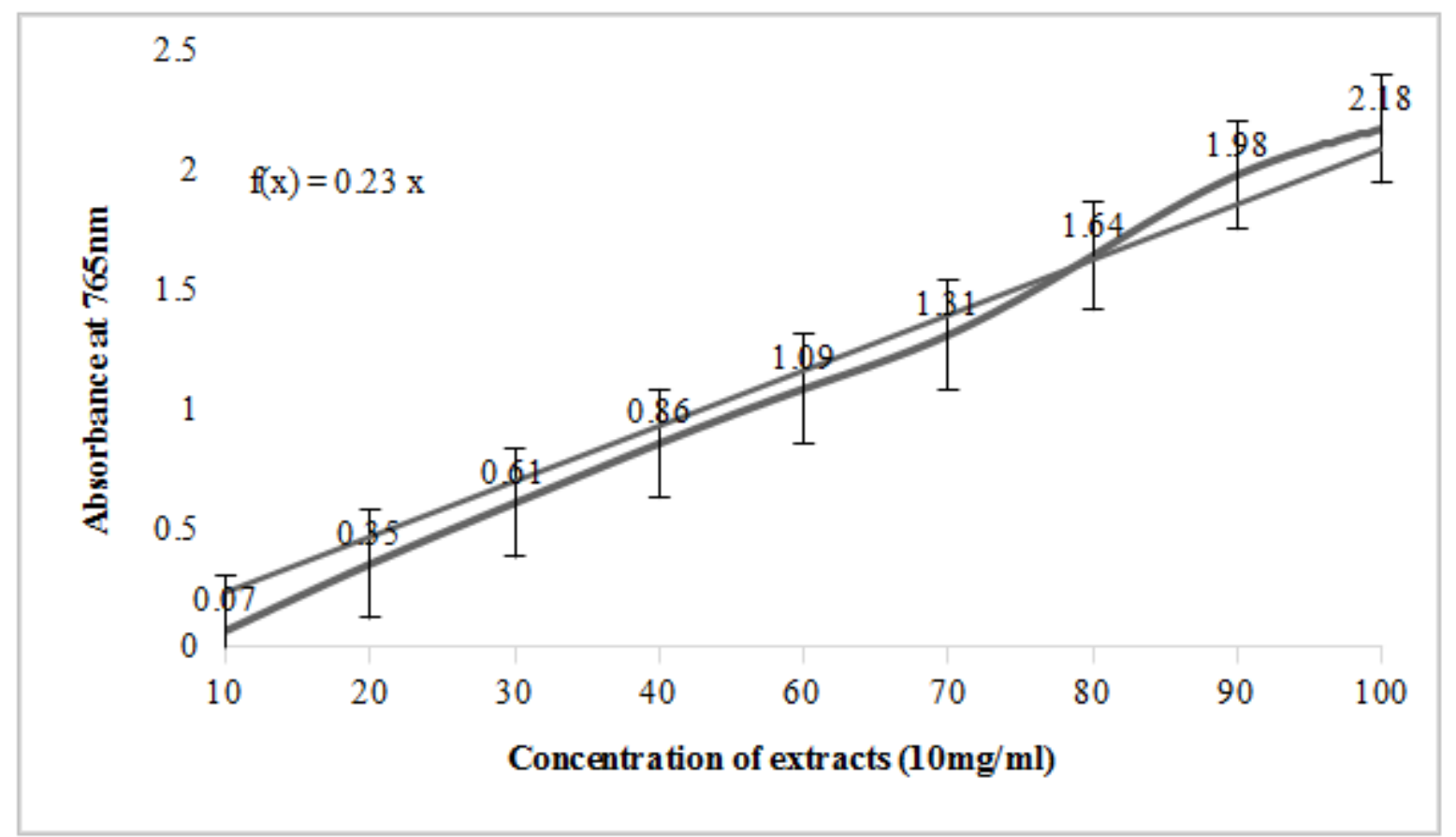

Fig. 3. Text figure is the standard graph of gallic acid for estimating total phenolic content of $O$. mungos var. angustifolia. The total phenolic content $(x)$ was calculated from the regression equation of calibration curve where ' $y$ ' is the absorbance. Data represent the mean of three replicates \pm SD.

assay of total anti-oxidant capacity and Nitric oxide scavenging activity assay. The $\mathrm{IC}_{50}$ value was calculated and mentioned in the Table 1.

Plants rich in secondary metabolites have antioxidant activity due to their redox properties and chemical structures. The hexane and methanol extract of $O$. mungos var. angustifolia had moderate antioxidant activity against investigated free radicals. The DPPH radical is widely used in assessing free radical scavenging activity because of the ease of the reaction. $\mathrm{IC}_{50}$ value of DPPH scavenging activity was $65.37 \pm 4.97$ $\mu \mathrm{g} / \mathrm{mL}$ in hexane and in methanol extracts while that of the control, ascorbic acid, was $66.69 \pm 5.63$ $\mu \mathrm{g} / \mathrm{mL}$. The molecule DPPH is characterized as a stable free radical by virtue of the delocalisation of the spare electron over the molecule as a whole, so that the molecule does not dimerize, as would be the case with most other free radicals (34).

In ferric chloride reducing power assay, the $\mathrm{Fe}^{3+}-\mathrm{Fe}^{2+}$ transformation in the presence of the extracts was assessed. The reducing power of extracts and ascorbic acid, used as reference compound, were assayed and the results are shown in Table 1 . Both extracts have moderate level of reducing power activity than ascorbic acid. In our work a correlation between reducing power activity of extracts and polyphenol and flavone content of them can be observed as in other studies $(35,36)$.

The present study hexane $\left(\mathrm{IC}_{50}=105.2 \pm\right.$ $5.00 \mu \mathrm{g} / \mathrm{mL}$ ) and methanol $\left(\mathrm{IC}_{50}=328.7 \pm 7.67\right.$ $\mu \mathrm{g} / \mathrm{mL}$ ) extracts of $O$. mungos var. angustifolia may be act as antioxidant by inhibiting the production of nitric oxide. Nitric oxide is a lipophilic molecule. At physiological $\mathrm{pH}$ it reacts with oxygen to produce stable products (nitrate and nitrite), the quantities of which can be determined using Griess reagent (37). Scavengers of nitric oxide compete with oxygen and inhibit the production of nitric oxide (38).

Total antioxidant capacity of hexane and methanolic extracts was determined using phosphomolybdate assay (Table 1). The assay is based on the fact that molybdenum (VI) is reduced to molybdenum $(\mathrm{V})$ in the presence of a reducing agent (antioxidant), forming a green phosphomolybdate (V) complex, which can be evaluated spectrophotometrically at $765 \mathrm{~nm}$ (39). The assay involves an electron transfer mechanism. Many natural products, including phenols and flavonoids, can cause this reduction.

\section{Anti-bacterial and antifungal studies}

The hexane extract of the plant showed activity against gram positive bacteria; Bacillus subtilis and gram negative bacteria; E. coli, Klebsiella pneumonia, Staphylococcus aureus. It also showed moderate activity against the fungi Colletotrichum gloeosporioides and Aspergillus niger (Supplementary data 1). The antibacterial activity of the hexane and methanol extract shown in the Table 2.

Plants with their bioactive chemical compounds, serve as plant defense mechanisms against invasion by microorganisms $(40,41)$. It was due to the differences in the phyto-constituents of the extracts. In the present analysis it was observed that the plant extracts have considerable bactericidal activity against gram positive, gram negative and fungus in hexane extract only while there is no antimicrobial activity in methanol 
Table 2. Antibacterial and antifungal activity of hexane and methanol extract of $O$. mungos var. angustifolia

\begin{tabular}{|c|c|c|c|}
\hline & \multirow{2}{*}{ Micro organisms } & \multicolumn{2}{|c|}{ Zone of inhibition (mm) } \\
\hline & & Hexane extract & Methanol extract \\
\hline \multirow[t]{4}{*}{ Bacteria } & Escherichia coli & $9.66 \pm 0.802$ & Nil \\
\hline & Bacillus subtilis & $6.63 \pm 0.665$ & Nil \\
\hline & Klebsiella pneumonia & $6.33 \pm 1.050$ & Nil \\
\hline & Staphylococcus aureus & $10.53 \pm 0.709$ & Nil \\
\hline \multirow[t]{2}{*}{ Fungi } & Aspergillus niger & $5.36 \pm 0.832$ & Nil \\
\hline & Colletotrichum gloeosporioides & $11.56 \pm 0.702$ & Nil \\
\hline
\end{tabular}

Data represent the mean of three replicates \pm SD.

extract and camptothecin (Suppementary data 1). This may be due the methanol extract has only camptothecin and its derivatives, HPLC data corroborate with the result. $O$. mungos var. angustifolia is herbaceous medicinal plant and its large scale multiplication is a good alternative system for the isolation of camptothecin in industrial level.

\section{Acknowledgements}

The authors thank to University of Kerala, Thiruvananthapuram, and Kerala for providing the necessary facilities. The authors thanks to Kerala state council for science technology and education (KSCSTE) for providing the financial support.

\section{Author's contribution}

$\mathrm{KK}, \mathrm{MF}$ and JK contributed to the design and implementation of the research, to the analysis of the results and to the writing of the manuscript.

\section{Competing Interests}

The authors have no conflict of interest.

\section{References}

1. Mabberly DJ, Mabberley's Plant- book A portable dictionary of plants, their classifications and uses, 3rd ed. Cambridge University Press: New York; 2008. P. 603.

2. Sibi CV, Dintu KP, Renjith R, Krishnaraj MV, Roja G, Satheeshkumar K. A new record of Ophiorrhiza trichocarpon Blume (Rubiaceae: Ophiorrhizeae) from Western Ghats, India: Another source plant of camptothecin, J. Sci. Ind. Res. 2012; 4: 529-532. https://doi.org/10.3329/jsr.v4i2.9378

3. Hareesh VS, Sreekumar VB, Prabhukumar KM, Sabu M, Sreejith KA, Lectotypification of Ophiorrhiza heterostylaDunn and the new record of Ophiorrhiza rugos Wall. var. angustifolia (Thwaites) Ridsale (Rubiaceae) for India. J. Webbia. 2014; 70: 109-112. https://doi.org/10.1080/00837792.2015.1015249

4. Hareesh VS, Sreekumar VB, Kumar KMP, Nirmesh TK, Sreejith KA. Ophiorrhiza sahyadriensis (Rubiaceae), a new species from southern Western Ghats, Kerala, India, 2015; 202: 2014-2016.

5. Sibi CV, Renjith R, Dintu KP, Ravichandran $P$, Satheeshkumar K. A new record of Ophiorrhiza wattii (rubiaceae: ophiorrhizeae) for Western Ghats, India - a source of an anticancer drug. J. Sci. Res. 2015; 246: 2006-2009.

6. Kitajima M, Fujii N, Yoshino F, Sudo H, Saito K, Aimi N, Takayama H. Camptothecins and two new monoterpene glucosides from Ophiorrhiza liukiuensis. Chem. Pharm. Bull. 2005; 53: 1355-1358. https://doi.org/10.1248/cpb.53.1355

7. Cunningham D, Pyrhonen S, James RD, Punt CJ, Hickish TF, Heikkila R, Johannesen TB, Starkhammar H, Topham CA, Awad L, Jacques C, Herait P. Randomised trial of irinotecan plus supportive care versus supportive care alone after fluorouracil failure for patients with metastatic colorectal cancer. Lancet. 1998; 352: 1413-1418. $\quad$ https://doi.org/10.1016/S01406736(98)02309-5

8. Douillard JY, Cunningham D, Rothm AD, Navarro M, James RD, Karasek P, Jandik P, Iveson T, Carmichael J, Alakl M, Gruia G, Awad L, Rougier P. Irinotecan combined with fluorouracil compared with fluorouracil alone as first-line treatment for metastatic colorectal cancer: a multicentre randomised trial. Lancet. 2000; 355: 1041-1047. $\quad$ https://doi.org/10.1016/S0140$\underline{6736(00) 02034-1}$

9. Wall ME, Wani MC. History and future prospects of camptothecin and taxol. In The Alkaloids, Chem. and Biol. 1998; 50: 509-536. https://doi.org/10.1016/S10994831(08)60051-6

10. Govindachari TR, Viswanathan N. Alkaloids of Mappia foetida. Phytochem. 1972. 11: 3529-3531. https://doi.org/ 10.1016/S0031-9422(00)89852-0

11. Gunasekera SP, Badawi MM, Cordell GA, Farnsworth NR, Chitnis M. Plant anticancer agents X. Isolation of camptothecin and 9-methoxycamptothecin from Ervatamia heyneana, J. Nat. Prod. 1979; 42: 475-477. https://doi.org/10.1021/np50005a006

12. Renjith R, Sibi CV, Rajani K, Roja G, Ramaswamy V, Krishnan S, Sabulal B. Search for Camptothecin yielding Ophiorriza species from southern Western Ghats in India: A HPTLC- densitometry study. Ind. Crops. Prod. 2013; 43:472-47. https://doi.org/10.1016/j.indcrop.2012.07.054

13. Sasidharan N. Biodiversity documentation for Kerala. 6th part. Flowering Plants. KFRA: Thrissur; 2004. 
14. Jeeja JK, Gangaprasad A, Satheeshkumar K. In vitro mass multiplication and estimation of camptothecin (CPT) in Ophiorrhiza mungos L. var. angustifolia (Thw.) Hook. f. Industrial Crops \& Products. Ind. Crops. Prod. 2018; 119 :

64-72. https://doi.org/10.1016/j.indcrop.2018.03.061

15. Krishnakumar G, Rameshkumar KB, Priya S, Satheeshkumar $\mathrm{K}$ and Krishnan PN. Estimation of camptothecin and pharmacological evaluation of Ophiorrhiza prostrata D. Don and Ophiorrhiza mungos L. Asian Pac J Trop Biomed. 2012; S727-S731. https://doi.org/10.1016/S2221-1691(12)60304-9

16. Harborne JB. Phytochemical Methods. An Guide to Modern Techniques of Plant Analysis, Chapman and Hall, London Ltd. 1973.

17. Roja G, Heble MR. The quinoline alkaloids, camptothecin and 9-methoxy camptothecin from tissue cultures and mature trees of Nothapodytes foetida. Phytochem. 1994; 36: 65-66. https://doi.org/10.1016/S0031-9422(00)97013-4

18. Fulzele DP, Satdive RK, Pol B. Growth and production of camptothecin by cell suspension cultures of Nothapodytes foetida. Planta Med., 2001; 67: 150-152. https://doi.org/10.1055/s-2001-11519

19. Singleton VL, Orthofer R, Lamuela-Ravento's, R.M., Analysis of total phenols and other oxidation substrates and antioxidants by means of Folin-Ciocalteu reagent. Methods Enzymol. 1999; 299: 152-178. https://doi.org/10.1016/S0076-6879(99)99017-1

20. Villano D, Fernandez-Pachon MS, Moya ML, Troncoso AM, Garcia-Parrilla MC. Radical scavenging ability of polyphenolic compounds towards DPPH free radical, Talanta. 2007; 71: 230-235. https://doi.org/10.1016/j.talanta.2006.03.050

21. Oyaizu M. Studies on products of browning reactions: antioxidant activities of products of browning reaction prepared from glucosamine. J. Nutrit. 1986; 44: 307-315. https://doi.org/10.5264/eiyogakuzashi.44.307

22. Prieto P, Pineda M, Aguilar M. Spectrophotometric quantitation of antioxidant capacity through the formation of a phosphomolybdenum complex: specific application to the determination of vitamin E. Anal. Biochem. 1999; 269: 337-341. https://doi.org/10.1006/abio.1999.4019

23. Marcocci I, Marguire JJ, Droy-lefaiz MT, Packer L. The nitric oxide scavenging properties of Ginkgo biloba extract. Biochem. Biophys. Res. Commun. 1994; 201: 748-755. https://doi.org/10.1006/bbrc.1994.1764

24. Shoib AB, Shahid AM. Determination of total phenolic and flavonoid content, antimicrobial and antioxidant activity of a root extract of Arisaema jacquemontii Blume. Journal of Taibah University for Science. 2015; 9: 449-454. https://doi.org/10.1016/j.jtusci.2014.11.001

25. Chatha SAS, Anwar F, Mazoor M. Evaluation of the antioxidant activity of rice bran extracts using different antioxidant assays. Grasas Y Aceites. 2006; 57:328-335.

26. Sultana B, Anwar F, Ashraf M. Effect of extraction solvent/technique on the antioxidant activity of selected medicinal plants extracts. Molecules 2009; 14: 2167-2180. https://doi.org/10.3390/molecules14062167

27. Tanaka K, Satokata I, Ogita Z, Uchida T, Okada Y. Molecular cloning of a mouse DNA repair gene that complements the defect of group-A xeroderma pigmentosum. Proc. Natl. Acad. Sci. U. S. A. 1989; 86: 5512-5516. https://doi.org/10.1073/pnas.86.14.5512

28. Rajani M, Ravishankar MN, Shrivastava N, Padh H. HPTLC-aided phytochemical fingerprinting analysis as a tool for evaluation of herbal drugs. A case study of Ushaq (Ammoniacum gum). J. Planar Chromatogr. 2001; 14: $34-41$

29. Tafur S, Nelson JD, De Long DC Voboda GH. Antiviral components of Ophiorrhiza mungos isolation of camptothecin and 10-methoxy-camptothecin. Lloydia 1976; 39: 261-262.

30. Van-Hegel AJ, Buitelaar RM, Wichers HBJ. Camptotheca acuminate Decne: in-vitro culture and the production of camptothecin. Biotechnology in agriculture and forestry. Springer- Verlag Berlin Heidelberg, New York; 1994: p. 98-112.

31. Sakato K, Misawa M. Effects of chemical and physical condition of growth of Camptotheca acuminata cell culture. Agric. Biol. Chem.1974; 38: 491- 497. https://doi.org/10.1080/00021369.1974.10861199

32. Yamazaki Y, Urano A, Sudo H, Kitajima M, Takayama H, Yamazaki M, Aimi N, Saito K. Metabolite profiling of alkaloids and strictosidine synthase activity in camptothecin producing plants. Phytochem. 2003; 62:461-70. https://doi.org/10.1016/S0031-9422(02)00543-5

33. Koleva TA, Van Beek JPH, Linssen AD, Evstatieva LN. Screening of plant extracts for antioxidant activity: a comparative study on three testing methods. Phytochem. Anal. 2002; 13:8-17. https://doi.org/10.1002/pca.611

34. Gulcin M, Elmastas HY. Aboul-Enein determination of antioxidant and radical scavenging activity of Basil (Oscimum basilicum L. family - Lamiaceae) assayed by different methodologies. Phyto. Res. 2007; 21: 354-361. https://doi.org/10.1002/ptr.2069

35. Duenas M, Hernandez T, Estrella I. Assessment of in vitro an tioxidant capacity of the seed coat and the cotyledon of legumes in relation to their phenolic contents. Food. Chem. 2006; 98: 95-103. https://doi.org/10.1016/j.foodchem.2005.05.052

36. Kilani S, Sghaier MB, Limem I, Bouhlel I, Boubaker J, Bhi W, Skandrani I, Neffatti A, Ammarb RB, Dijoux FMG, Ghedira $\mathrm{K}$ and Chekir GL. In vitro evaluation of antibacterial, antioxidant, cytotoxic and apoptotic activities of the tubers infusion and extracts of Cyperus rotundus. Bioresour. Technol. 2008; 99: 9004-9008. https://doi.org/10.1016/j.biortech.2008.04.066

37. Rees DD, Palmer RM, Moncada S. Role of endotheliumderived nitric oxide in the regulation of blood pressure. Proc Natl Acad Sci USA. 1989; 86: 3375-3378. https://doi.org/10.1073/pnas.86.9.3375

38. Malheiro R, Sa O, Pereira E, Aguiar C, Baptista P, Pereira JA. Arbutus unedo L. leaves as source of phytochemicals with bioactive properties. Ind. Crops Prod. 2012; 37: 473-478. https://doi.org/10.1016/j.indcrop.2011.07.023

39. Prieto P, Pineda M, Aguilar M. Spectrophotometric quantitation of antioxidant capacity through the formation of a phosphomolybdenum complex: specific application to the determination of vitamin E. Anal. Biochem. $1999 ; \quad 269$ : 337-341. https://doi.org/10.1006/abio.1999.4019

40. Abel C, Busia K. An explanatory ethnobotanical study of the practice of herbal medicine by the Akan peoples of Ghana”. Altern. Med. Rev. 2005; 10: 112-122.

41. Roosita K, Kusharto CM, Sekiyama M, Fachrurozi Y, Ohtsuka R. Medicinal plants used by the villagers of a Sundanese community in West Java, Indonesia. J. Ethnopharmacol. 2008; 115: 72-81. https://doi.org/10.1016/j.jep.2007.09.010 